Article

\title{
What Can Faith-Based Forms of Violent Conflict Prevention Teach Us About Liberal Peace?
}

\author{
Laura Payne $\mathbb{D}$ \\ Centre for Trust, Peace and Social Relations, Coventry University, Coventry CV1 5FB, West Midlands, UK; \\ laura.payne@coventry.ac.uk
}

Received: 7 January 2020; Accepted: 25 March 2020; Published: 3 April 2020

\begin{abstract}
Faith-based actors are often recognised as contributors to both conflict and peace. However, their work to prevent violent conflict, rather than bring an end to or recover from it, is largely unexplored. This is despite the growth of conflict prevention as a global social norm and field of practice. Based on collaborative research with faith groups and organisations in Nigeria, the Solomon Islands and Zanzibar (Tanzania), this paper examines faith-based forms of violent conflict prevention. It argues that faith-based approaches exist on a spectrum, from instinctive and ad hoc initiatives run by individuals and local places of worship to large-scale, systematised interventions led by global faith-based development organisations. Yet, while faith-based approaches to violent conflict prevention vary in form and function, they are consistent and distinctive in their emphasis on building resilient relationships at the local level, modelling forms of prevention embedded within local culture and that recognise the emotional and spiritual dimensions of transformative change. Faith-based approaches offer insights valuable to the wider conflict prevention field, which is increasingly critiqued for its liberal underpinnings and emphasis on technical and technological solutionism. Lessons emerge for others implementing prevention programmes, who could adapt elements of the unhurried, values-led, relationally sensitive approach demonstrated by some faith-based actors, albeit within their own structural limitations. Policymakers should support such adaptations and expand their view of prevention to explicitly include faith-based forms of activity, as to do otherwise risks missing opportunities and reproducing existing failures.
\end{abstract}

Keywords: conflict prevention; faith; religion; liberal peace; peacebuilding; religious violence; technocracy; technology

\section{Introduction}

From the atrocities of Boko Haram and Daesh to the state-sponsored persecution of Myanmar's Rohingya, religiously framed violence dominates headlines and plagues lives. On the flip side, religious actors are also recognised for their efforts to disavow violence and support peace. Whilst both of these constructs are familiar, the roles that religious actors play in preventing outbreaks of political violence are largely unknown (Haider 2016). Based on case studies from Nigeria, the Solomon Islands and Zanzibar, this article introduces examples of faith-based conflict prevention at local and national levels. It considers the contexts in which faith-based conflict prevention occurs and the forms it takes, from reflexive offers of sanctuary and safe passage to early warning and response to long-term efforts to address structural conflict drivers and challenge cultures of violence. It investigates how faith-based approaches conform with, contradict and extend conventional "liberal peace" wisdom and what the implications of this are for conflict prevention as a field of practice.

Faith-based actors range in form, from local faith groups and places of worship, some informally constituted, to international development agencies and global religious movements. All derive inspiration and guidance from the teachings and principles of their faith or a particular interpretation or 
school of thought within that faith (Clarke et al. 2008). In times of violent conflict and in the aftermath, some seek to build peace and lay foundations for recovery, shaping their existing activities to support peacebuilding or taking on new roles. Some faith-based actors function very similarly to non-faith-based peacebuilding actors-in larger faith-based international development agencies, in particular, day-to-day working practices may be largely indistinguishable from others in the sector.

Recent years have seen major faith-based humanitarian organisations enter peacebuilding programming in a more sustained way. Organisations such as Islamic Relief, Christian Aid and Tearfund have recalibrated their activities in conflict-affected areas, supplementing conflict-sensitive development work with activities more explicitly framed as peacebuilding. This responds to growing donor interest, both in partnering with faith-based organisations (Duff et al. 2016) and in peacebuilding. As engagement has increased, debates around working with faith-based actors have matured. Questions of appropriate forms of partnership have come to the fore, along with concerns over instrumentalisation of faith partners and low levels of faith literacy within the development sector. New platforms for partnership have been created, along with "principles" (DfID 2012) and "partnership notes" (UNHCR 2014) to guide interactions.

The growth in faith-based peacebuilding has coincided with the development of conflict prevention as a distinct global norm and field of practice. The latter provides a framework to consider the preventative contributions of faith-based actors, but so far, the literature on the two subjects remains largely separate. This contrasts with the wealth of literature on religion and countering violent extremism or religion and atrocity prevention, which both have a similarly proactive approach to addressing violence. Recognising this knowledge gap, the article integrates the literature on conflict prevention, liberal peace and faith-based peacebuilding and analyses the implications of faith-based initiatives for the prevention agenda and liberal peace more generally. It is significant in a number of ways. Firstly, it contributes to the knowledge base on conflict prevention by expanding the view to include faith-based initiatives, which opens up space for critical reflection of current prevention practice and reveals new pathways for reform. Secondly, it contributes to debates within the faith-based peacebuilding literature, as it sets out the parameters of faith-based conflict prevention, as yet unestablished, and identifies avenues for further research in this underexplored area. Finally, this article recommends ways to adapt programming to enable deeper engagement as calls for prevention grow stronger.

The paper continues with a brief methodological overview. It then provides a brief overview of approaches to religion within peace studies, recognising the ambivalent heritage that religious actors have as instigators and inhibitors of violence. Section 4 examines conflict prevention, charting its evolution from generic aspiration to global social norm and field of practice, and Section 5 considers conflict prevention as an extension of the liberal peace agenda. Section 6 documents case studies of faith-based forms of conflict prevention, identifying common themes linked to the faith-based organisations' dual identities as local and spiritual actors. Three persistent weaknesses of conflict prevention are then unpacked in order to examine the extent to which faith-based initiatives conform with, contradict and extend conventional "liberal peace" wisdom. The final section concludes, reflecting on the extent to which faith-based initiatives can add value and identifying pathways for future research.

\section{Methodology}

The data that inform this research were collected through two projects. The first was The Faith-Based Conflict Prevention and Early Warning Scoping Project, a collaboration between academics and the Anglican network of churches, the world's third largest church grouping. The project analysed the experiences of faith groups working to prevent conflict in Nigeria and the Solomon Islands through interviews, focus groups and participant observation at meetings and workshops, exploring what is distinctive about faith-based approaches. In the Nigerian cities of Jos and Kaduna, researchers engaged with 249 respondents across 30 organisations in 32 sessions, observing interfaith organisations as well as Christian-led initiatives. In Honiara, Solomon Islands, researchers interviewed 23 leaders from faith 
organisations and other entities, interacting with 98 additional respondents through workshops and faith group activities. Respondents included members of the Melanesian Brotherhood, an Anglican religious order of lay brothers unique for its large size and relative youthfulness, as the option to renew vows intermittently makes it a popular choice for young men to live in a spiritual community for a fixed time. In both contexts, respondents included a mix of ordained faith leaders and lay people, peacebuilding practitioners and development workers, community members involved in peacebuilding activities, and donors and policymakers.

Data also come from a second project, From Early Warning to Response in Preventing Violence: Transforming Conflict Through Citizen Engagement, in collaboration with the Action Support Centre (South Africa). Through participatory action research, the project investigated the effectiveness of information, communication and technology (ICTs) in conflict early warning and early response initiatives. This paper includes insights from Zanzibar, a semi-autonomous region of Tanzania, where the local partner was the Zanzibar Interfaith Centre.

A full analysis of the conflict dynamics in each area is beyond the scope of this paper, but extensive conflict analyses were conducted with partners in each country to situate the research, mapping conflict issues, key stakeholders and peacebuilding assets. In all cases, respondents identified multiple competing forms of conflict. In Nigeria and Zanzibar, respondents identified religious dimensions to conflicts, though this was not necessarily the central issue. Often, religion was the fault line upon which opinion was divided or a surface narrative framing other concerns. In Zanzibar, for instance, a prescient issue for respondents was unease with rapid modernisation and Westernisation, epitomised through mass tourism. Zanzibaris receive minimal financial benefit from this, whilst struggling to cope with the associated uncontrolled migration and perceived moral decay (Keshodkar 2013). According to local partners, religion intersects by providing an Islamic moral traditionalism as an alternative to "Western" immodesty and decadence. In all areas, religion was identified as one of many identity markers influencing peace and conflict dynamics, alongside others such as ethnicity, indigeneity and class.

For both projects, the interviews, focus groups and workshops were designed by a mixed team of academic researchers and faith-based research partners. For each session, responses were transcribed by two researchers who later validated their findings with each other. Data were grouped into themes by the team, and synthesised findings were later presented to a wider group of external stakeholders, both faith-based and secular, who have experience and expertise in the sector.

As the literature review will show, the academic exploration of faith-based forms of conflict prevention is in its infancy. An empirical approach, based on case studies, was chosen to gain an overview of the substance, extent and impact of faith-based conflict prevention initiatives. The format of knowledge exchange with faith-based partners was also important, as it provided ways to bridge contextual and thematic expertise, mitigate asymmetric power relationships, avoid extractive research, recognise colonial legacies and ultimately "do no harm". The methodology reflects a move towards participatory approaches and knowledge networking with religion and development (Bompani 2019) and peace studies (Verkoren 2006) more generally. These forms of research come with challenges, notably the possible influence of partners' biases on the research process and findings. Researchers were mindful of this and introduced checks and balances, including systematic research design and external feedback, but ultimately found that working within mixed academic/practitioner and secular/faith-based teams supported a research culture that was conscious of positionality, reflective and frank in assessing successes and failures.

In analysing faith-based forms of conflict prevention, both projects avoided seeking grand theories and narratives to "explain" the phenomenon. Scholars have often highlighted the pitfalls of making sweeping statements regarding the roles of religious actors in peace and conflict, instead recognising the overall "ambivalence of the sacred" (Appleby 2000; Philpott 2007). Ultimately, this article seeks to identify what faith-based forms of conflict prevention can be, rather than what they definitively are. 


\section{Religion, Conflict and Peacebuilding}

Links between religion, conflict and violence are complex and much interrogated, but those between religion and peacebuilding receive less attention. This reflects a tendency of scholars to study peace through its absence rather than its presence and the biases of a largely secular academy (Shannahan and Payne 2016). Within the social sciences, religion is often side-lined, including in disciplines such as international relations (Johnston and Sampson 1994) and development studies (Bompani 2019). Within peace studies, however, a strong and coherent body of scholarship around religious engagement in peacebuilding has emerged. Many analyses of this coalesce around Appleby (2000) work on the "ambivalence of the sacred", which acknowledges that religious actors are important "purveyors of ideas" (Haynes 2011) capable of driving both conflict and peace. Scholars have examined a spectrum of different forms of faith-based action, including in mediation, dialogue and track-II diplomacy (Bercovitch and Kadayifci-Orellana 2009; Toft et al. 2011; Johnstone and Svensson 2013), humanitarianism, development and displacement (Ager et al. 2015), and post-conflict reconstruction, reconciliation and trauma resolution (Putman et al. 2011). Case studies document initiatives within Christianity (Sampson and Lederach 2000; Appleby 2000; Johnston and Sampson 1994), Islam (Abu-Nimer 2003) and non-Western religions (Galtung and MacQueen 2008; Neumaier 2004). A growing body of work also highlights the role of religious women in peacebuilding (Hayward 2015; Hayward and Marshall 2015).

\section{The Evolution of Conflict Prevention as a Global Norm and Field of Practice}

In essence, conflict prevention is the effort to prevent tomorrow's violence today. As such, it is relevant at any stage of conflict where violence is anticipated. It requires the proactive identification of conflict triggers and a subsequent response to prevent violence from breaking out or escalating and thus entails both foresight and action. Operational prevention responds to the imminent onset of violence through early warning and response, often using monitoring data provided by field monitors, volunteers or the public. Flagship initiatives have emerged, including CEWARN, an East African model to prevent cross-border pastoralist conflicts through stakeholder collaboration, information sharing and formulating response options. Structural prevention addresses the underlying causes of conflict, aiming to transform these for the long term. The drive for prevention stems from the recognition that prevention is cheaper than cure (Chalmers 2006) and awareness that conflict is a barrier to progress, exacting a heavy toll on human life and on economic, social and political systems. It also reflects a turn to discourses of prevention and precautionary policymaking more generally, in areas as varied as health, early years interventions, poverty, criminality and climate change (Coote 2012; Gough 2013).

Conflict prevention is at the United Nations' (UN) core, with its renowned preamble beginning, "We the peoples of the United Nations determined to save succeeding generations from the scourge of war, which twice in our lifetime has brought untold sorrow to mankind ... ". Its development as a global norm and field of practice came in the Boutros-Ghali era, with the development of "preventative diplomacy" in the 1992 Agenda for Peace. Successive Secretary Generals maintained focus, with Annan shifting to a "culture of prevention", Ban Ki-Moon declaring 2012 the "year of prevention" and current Secretary General Guterres declaring prevention the number one priority. The Responsibility to Protect (R2P) was adopted by all UN member states in 2005, with the UN developing early warning capacity to prevent genocide, ethnic cleansing and crimes against humanity.

At the regional level, the European Union (EU) adopted conflict prevention as an explicit objective through the Lisbon Treaty (Vanheusden 2010). The African Union (AU) developed preventative tools within the Africa Peace and Security Architecture. In 2017, it adopted the AU Master Roadmap on Practical Steps for Silencing the Guns by 2020. The Association of Southeast Asian Nations (ASEAN) has focused on "preventative diplomacy", a state-centric approach to prevent conflict between member states while respecting strong norms of sovereignty that exist within the region (Della-Giacoma 2011). Other regional and sub-regional organisations have their own frameworks. Whilst the development of prevention architectures at regional level is undoubtedly positive, they do not always live up to 
expectations. Wulf and Debiel (2009) cite the difficulty of navigating different values and conceptions of sovereignty, lack of coordination and capacity and dominant regional powers as stumbling blocks.

The practice of conflict prevention originally lagged behind its development as a global norm (Aggestam 2003) but has grown significantly. Whilst early generations of operational prevention tended to be internationally driven, recent initiatives are likely to be community focused and technology enabled. Local actors are now perceived to have several advantages over international organisations, including flexibility, efficiency, approachability and familiarity with culture and context. Forms of programming have become more imaginative, with interventions based on crowdsourcing, GPS mapping and big data being piloted and mainstreamed. Alongside civil society programmes, there has also been a "privatisation" of prevention, with the business sector developing its own initiatives in response to public pressure (Haufler 2004). These tend to focus on the extractive industries, with a prominent example being the Kimberley Process Certification Scheme for diamond mining (Haufler 2010).

As conflict prevention has developed, criticisms have emerged that its practice appears weak compared to its promise (Aggestam 2003; Matveeva 2006; Wulf and Debiel 2009). Operational and structural approaches are not always well aligned, reflecting their divergent understandings of conflict and prevention (Aggestam 2003). Indicators that facilitate operational prevention can have a "straight-jacketing" effect and provide a negative basis for analysis, measuring communities' risks and exposure to violence but not their resilience and capacities (Anderson and Wallace 2012). Challenges exist in relation to the credibility and reliability of evidence and a persistent gap often remains between warning and response. Community-based organisations may have been brought into the fold, but international actors often engage in ways that are extractive (Saferworld and Conciliation Resources 2016), for instance by harvesting early warning data from local partners upon which they are unable to act. Such engagement lacks effectiveness and is ethically questionable, as it depletes local partners of time and energy without the prospect of results.

Finally, the analysis and critique of conflict prevention has been hindered by a lack of conceptual clarity. Firstly, the term is overused within the peace studies literature and peacebuilding sector, where "prevention" is often used interchangeably with "peacebuilding" and "conflict resolution". This imprecision risks embracing initiatives where the term prevention has been adopted but the preventative element is not well developed. Secondly, the term conflict prevention is underused by local actors, including faith-based actors, who may have their own vernaculars or reject the labelling of their work this way. So, the challenge is two-fold: adopt a wide definition and the distinction with other forms of peacebuilding is unclear; adopt a narrow definition and local and faith-based initiatives may be excluded. This article strikes a balance by including all activities that are discernibly preventative, irrespective of whether the terminology of prevention is applied and by excluding activities that are claimed to be preventative but not demonstrated to be so. To assess preventative effect, the article utilises Coote (2012) distinction between upstream, midstream and downstream interventions. Upstream interventions seek to prevent harm before it occurs, targeting structural causes, midstream interventions mitigate the effects of harm and are usually targeted at "at risk" groups and individuals, and downstream interventions cope with the consequences of harm. Upstream and midstream interventions are included within the analysis, whereas downstream interventions are excluded. This allows the study to exclude forms of action that are based on what one respondent referred to as "the fire brigade approach", where action is only taken reactively.

\section{Conflict Prevention as an Extension of Liberal Peace}

Liberal peace claims to provide a universal ideology for peace, based on an international order of rational, democratic, secular, free-market and human rights-abiding states, together with technical processes and technologies to achieve it. For critics and proponents alike, it represents the internationalisation of a particular form of government-free market liberal democracy (Sabaratnam 2011). In conflict and post-conflict countries, liberal peace generally focuses on the structural reform 
of domestic institutions, the failures of which have arguably created the conditions for conflict to emerge. These reforms may seek to establish or alter the country's constitution, institutionalise democracy or raise capacity within key state functions such as the legislature, judiciary and security services. Such processes are political and very technical and so engender forms of peacebuilding that are top-down and highly professionalised. They are often promoted by the international community, which provides substantial engagement and sometimes muscular intervention in the way of humanitarian and development aid, peacekeepers and even occasionally full-scale military occupation. Whilst such substantial reforms may be contentious and destablising for any country, they are frequently enacted within "fragile states where customary law, traditional authorities and informal "indigenous" institutions often hold greater sway than the state (Boege et al. 2009).

Liberal peace has its strengths, particularly for those whose rights are insecure. Yet, it also has significant ideological baggage, including Eurocentrism, technocentrism and historic connections with empire (Richmond and Ginty 2015). Richmond (2009) argues that in many post-conflict environments, local opinion perceives liberal peace to be "ethically bankrupt, subject to double standards, coercive and conditional, acultural, unconcerned with social welfare, and unfeeling and insensitive towards its subjects". Imposed from above, it risks degrading into violence if its universal aspirations are not reflected on the ground (Richmond 2009). Critiques of liberal peace have come from those who seek improvements in theory and practice but fundamentally accept the paradigm and those radically opposed (Chandler 2010). Many critiques revolve around notions of the "everyday" and the "local turn", which recognise increased assertiveness by local actors and a loss of confidence by some international actors (Mac Ginty and Richmond 2013). The concepts of "hybridity" and "post-liberal peace" have also emerged, attempting to draw out more complex understandings of relationships between the local and the international in peacebuilding. However, these have also been critiqued by pro-liberal scholars, who argue that these concepts have not pointed to a clear alternative path for peacebuilding and that liberal peace has still done more good than harm (Paris 2010).

Historically, religion and liberalism have been uneasy bedfellows. Cavanaugh $(1995,2009)$ charts how early proponents of the modern state system perpetuated a "myth" of religious violence to legitimise its liberal and secular foundations. He argues that much of this so-called religious violence was actually "resistance of local elites to the state building efforts of monarchs and emperors" (Cavanaugh 2009, p. 177). Today, the liberal peace paradigm still struggles to contend with religion, particularly where it challenges secular sovereignty (Mullin 2010). Religious traditions are also forced to reckon with liberalism, generally operating within the paradigm with varying enthusiasm. Religious actors must also consider their own culpability for atrocities perpetrated under ostensibly liberal state-building, such as colonialism (Lynch 2015). Yet, as Gopin (2015) reminds us, it is easy to overstate the differences between liberal peace and religious models, as enlightenment principles such as peace, human rights and democracy are also rooted in religious texts and practices.

Over the past several years, religious peacebuilding scholars have begun to deconstruct liberal peace and its implications for faith-based peacebuilding. Appleby and Lederach offer a corrective in their concept of strategic peacebuilding (Lederach and Appleby 2010), which pursues peace with justice ("justpeace") and embraces elicitive methods that foreground indigenous knowledge and culture over expert input, shifting agency further towards the local (Appleby 2015). In substance and approach, strategic peacebuilding articulates at least a partial rejection of liberal peacebuilding, which Appleby characterises as "Western, bureaucratic, ends-driven, materialist and top-down" (Appleby 2015, p. 190).

Given the overwhelming pervasiveness of the liberal peace paradigm, the development of conflict prevention as norm and practice has necessarily taken place within it (Hauge et al. 2015). Most forms of conflict prevention have shorter term goals than peacebuilding, geared more towards the aversion of violence and the maintenance of stability, but its function is ultimately to provide an enabling environment for liberal peacebuilding. The practice of prevention also shares key characteristics with liberal peace, with its privileging of external knowledge and models and its technocratic approach. The literature examining conflict prevention as a liberal peace project is small but critical. Jacobsen 
and Jacobsen and Engell (2018) argue that prevention is an extension of liberal interventionism. Their view is that interventionism has retreated but has been replaced by new forms of technology-enabled intervention under the rubric of prevention. Others argue that liberal peace approaches to prevention can undermine communities' capacity to prevent conflict, for instance by omitting to identify what is already working locally (Anderson and Wallace 2012) or by emphasising security and political reform at the expense of socio-economic changes (Hauge et al. 2015).

Many of the key criticisms of conflict prevention emerge from its ideological underpinnings in the liberal peace. Here, this paper briefly analyses three-its technocratic disposition, overreliance on information and communication technologies (ICTs) and short-termism. These are not the only criticisms of liberal peace, and they are not all to which liberal peace should be reduced. However, they are prominent and observable hallmarks of the concept that can be readily operationalised and thus provide a framework for comparing classical liberal peace interventions with those implemented by religious actors. The paper revisits these three areas again later to consider the potential value added by faith-based approaches.

\subsection{Technocratic Disposition}

Technocracy has its advantages, especially in conflict-affected environments (Mac Ginty 2018). However, liberal peacebuilding has been criticised for being increasingly technocratic and professionalised, which poses barriers to local ownership and participation. Kurtz and Meyer (2018) argue that technocratic understandings of conflict prevention are now widespread, based on positivist conflict forecasting and toolbox approaches to "what works", delivered with a heavy dose of "wishful thinking" about warning-response dynamics. They call for greater focus on the "art" of conflict prevention, paying closer attention to the informal, individual and political dimensions of the endeavour. Religious peacebuilding scholars have also underlined the creativity and discernment needed for sustainable peacebuilding, which technocracy and formulaic approaches can stifle. As Lederach (2001, p. 203) notes, "Authentic reconciliation will never be packaged and delivered at drive-through windows".

\subsection{Over-Reliance on Information and Communication Technologies}

ICT for conflict prevention has had some high-profile successes, such as the Ushahidi project's mapping of election violence ${ }^{1}$ and Una Hakika's countering of misinformation through its "WikiRumours" software. ${ }^{2}$ At their best, ICTs facilitate information sharing, communication and coordination, all of which are essential for collective action. Yet, they are not neutral tools, and their deployment is both shaped by and shapes political economy. Where violence arises from a breakdown in communication or a lack of accurate information, tools that improve these can theoretically help to prevent violence (Martin-Shields 2013). However, of course, ICTs are not a panacea. Trust is a crucial element in peacebuilding (De Juan and Pierskalla 2014), and where this is low, ICTs may not be effective (Leach 2016). So far, evidence on the impact of technology-enhanced conflict prevention initiatives is mixed. Projects have often misfired, promoting supply-driven technical fixes, introducing unfamiliar and unsustainable technology and pushing technological solutions onto political problems (Leach et al. 2015).

\subsection{Short-Termism}

Sustainable conflict prevention involves substantive institutional reform to address structural drivers of conflict, requiring long-term engagement. Yet, the temporal aspect of prevention is often

1 Ushahidi means "witness" in Swahili. The Kenyan platform originally emerged to track post-election violence in the country in 2007-2008 but has now been used for many purposes across Africa.

2 Una Hakika means "You are Certain" in Swahili. The initiative seeks to verify information and counter rumours. 
overlooked by donors and policymakers. In fact, the liberal peace toolbox seems a hindrance to appropriate timing, given that donors tend to withdraw their engagement when risks escalate and political actors only engage when the risk of violence is high or violence is already present (United Nations and World Bank 2018).

\section{Faith-Based Conflict Prevention}

There have been very few substantive analyses of faith-based violent conflict prevention in the academic literature. Notable exceptions include Hertog (2010), who explores the peace-inculcating values and ethics of religion and the potential of these for violence prevention, and Palihapitiya (2018), who considers faith-based early warning systems. A small number of policy-focused reflections exist (Haider 2016; Perchoc 2016). This is despite the fact that initiatives have long been common at the local level, where religious actors are well placed to respond to early signs of violence and are increasingly being adopted by international faith-based NGOs. National-level religious leaders often have public platforms to raise the alarm as peace deteriorates. Internationally, many larger faith traditions have secretariats and representatives at global institutions, through which they can raise issues on the global stage. As examples, the Holy See is a permanent observer state at the United Nations, and the Anglican Communion also retains a representative to the United Nations in Geneva and New York.

In all of the case studies, respondents evidenced a range of faith-based conflict prevention initiatives. During the conflict in the Solomon Islands, young monks slept on the battle lines in a "middle camp" between warring militias. They provided security at the airport, allowing planes importing vital goods to land and preventing further deterioration of law and order. Church leaders escorted people in danger, providing safe passage and sanctuary. In the aftermath, monks collected weapons on behalf of the Regional Assistance Mission to the Solomon Islands (RAMSI), preventing retaliatory gun violence. Church leaders mediated local disputes around land to prevent them spiralling. They brokered interpersonal and communal reconciliation and healing and ran training workshops on non-violent conflict resolution. Churches were instrumental in establishing a Truth and Reconciliation Commission, which included a forward-looking set of reforms "designed to prevent a recurrence of violence" (Jeffrey and Mollica 2017). When the government refused to release the Commission's report, one Bishop controversially leaked it to the media.

In Nigeria, religious peacebuilding initiatives were mostly led by local faith-based NGOs with strong ties to religious communities. Conflict prevention activities included the formation of conflict early warning and response teams and GPS mapping of violence. One organisation literally counted the costs of conflict with villages (what is the cost of a dead cow, a burned-out building, the loss of a breadwinner). Thinking long term, another organisation ran interfaith youth livelihood programmes, including a residential farm bringing together Christian and Muslim youth from different ethnic groupings in shared dormitories. Women's faith groups ran religious literacy classes with prisoners, pushing back against attempts to justify violence through religious doctrine. A high point for religious peacemakers was the signing of the Kaduna Peace Declaration of Religious Leaders in 2002. Musa (2016) argues that this had an immediate preventative effect: when Kaduna's Muslim youth rioted against Nigeria hosting the Miss World Beauty pageant, Christian and Muslim leaders were proactive in quelling violence. A total of 250 people were killed in the Miss World riots; two years previously, the shari'a riots claimed over 2500 lives.

Finally, in Zanzibar, a Joint Committee of Religious Leaders regularly sought to deescalate tensions by dispelling rumours and appealing for calm. An interfaith organisation ran activities to promote peace during elections, improve community policing and enable youth to advocate for peace. They have also set up more than 300 local peace committees throughout the island to monitor peace. ${ }^{3}$

3 An in-depth analysis of the Committee's work has been conducted by Langås (2019). 
In all cases, respondents could identify highly localised indicators of potential violence. These included chieftain disputes, lorries on the road at night (signifying illicit activities and the breakdown of law and order), violence in neighbouring areas, the unexpected arrival of strangers, rumours circulating by SMS, a ban or curfew on motorcycle drivers, adversaries relocating cattle, circulation of leaflets in the market and proselytising during other faiths' religious holidays. Longer term indicators included "irregular" migration (with irregular in this instance referring to migration against customary practices), ethnic segregation/ghettoisation of inner-city areas, the sweeping aside of unaddressed grievances and rapid cultural change/Westernisation. Respondents could also connect these to global triggers, including the Danish cartoon controversy of 2002, in which a Danish newspaper published cartoons depicting the Prophet Mohammed as a terrorist, and the fall of Gaddafi in Libya, which increased access to small arms.

In conducting their prevention activities, faith-based actors were found to benefit from three forms of overlapping capital: local capital, on the one hand, and religious and spiritual capital on the other. In this article, local capital refers to the strengths and advantages that local actors may have by virtue of their positioning and proximity to communities. As such, it is an extension of social capital, a term popularised by Putnam (2000) to denote a public good derived from "connections among individuals-social networks and the norms of reciprocity and trustworthiness that arise from them". In the case studies, local faith-based organisations often utilised local capital-they were quick to pick up on and interpret subtle changes in conflict indicators, given their familiarity with local norms, culture, practices and vernacular. They were also known entities with an existing store of goodwill upon which to draw.

Religious capital refers to the practical contributions made by faith groups based on their resources, while spiritual capital refers to the ethical, theological, scriptural and spiritual values that energise this (Baker 2009). Some definitions combine both forms of capital under the same heading of either "religious" or "spiritual", but there is greater conceptual clarity in separating the two. "The spiritual is associated with the personal, the intimate, the interior and the experiential, contrasted with 'religion', which is associated with the official, the external and the institutional, often picking up negative connotations of the hierarchical and patriarchal along the way" (Guest 2007; Heelas 2002). Of course, a long tradition of philosophers, from Marx (1844) to Weber (1964) to Bourdieu (1987), highlight that the use of religious and spiritual capital is not always benign. Few religious peacebuilding scholars would dispute this-indeed, it is further evidence of the ambivalence of the sacred.

In the case studies, faith-based actors strongly utilised their religious capital. Most had access to well-located premises for meetings and activities. Often, religious leaders had access to other local leaders, including those in politics, media and the aid sector. In Nigeria, some faith leaders had their own TV talk shows. Depending on their circumstances and institutional structures, many leaders could escalate matters to national and international leaders through denominational, ecumenical and interfaith networks. Faith groups also had their own financial resources, which, though small, offered a level of stability and continuity.

Critically, faith groups also utilised their spiritual capital. Activities observed by the research team were distinctly value driven, emphasising concepts of justice, compassion and human flourishing and affirming these through prayer and the use of religious doctrine, storytelling and symbolism. This was done as a matter of conviction, rather than utility, but nevertheless had the potential to allow people to move beyond their own interests and look at the common good. The use of religious ritual and symbolism was often important for communities-in the Solomon Islands, the hands of former combatants were symbolically washed when they handed over their weapons, signifying a spiritual cleansing that was meaningful for them. Respondents explained how prevention activities were designed to connect at an individual's innermost levels, going beyond the cognitive to enter what some might see as a spiritual realm or what others might see as an emotional or psychological one. 
Only church vehicles could pass through the [militia] camps, but once our vehicle was stopped. The priest came back and told me, and I said 'go and tell them that vehicle is a church. If they hold it, they are holding a church'. (Christian faith leader, Solomon Islands).

This readiness to engage more deeply is important, as emotions are an essential part of transforming conflict (Bramsen and Poder 2018). It also gives activities credence: "You need some theological basis, or this is just a government agenda" (Christian faith leader, Nigeria).

Of course, faith-based engagement in conflict prevention is far from perfect. Some religious actors are openly hostile to such initiatives and may even be key conflict protagonists. In Nigeria, respondents explained that hate preaching by religious leaders contributes to violence: "Before preaching was very balanced, but today it can be too extreme" (Muslim faith leader, Nigeria). Nor are faith-based actors immune from the creeping elitism that the wider field of conflict prevention has been charged with. "Interfaith work is all up, up, up, they will continue going up until they meet Jesus! But there are people down there. We need to go much more local. Relationships have to be formed at a local level, between youth" (Christian youth leader, Nigeria). Where faith groups have a middle-class bias, they can also struggle to access those most easily mobilised into violence, who are often youth from poor families. In the Solomon Islands, the monks of the Melanesian Brotherhood were roughly the same age as the militias and, in some cases, had been to school with them, enabling them to build rapport. In Nigeria, however, one civil society leader observed that religious leaders were losing influence over youth, with implications for their prevention work: "The religious leaders aren't following youth, they aren't at the football fields, and youth are major actors" (Civil society leader, Nigeria).

\section{Conflict Prevention: Lessons from Faith-Based Initiatives?}

This final section of the paper revisits the three criticisms of conflict prevention set out earlier and identifies the potential added value of faith-based initiatives.

\subsection{Technocratic Disposition}

In the case studies, faith-based organisations tended to prioritise relationship-building and shifts in perspective ahead of tactical attempts to moderate or problem-solve issues. After all, "When you develop infrastructure instead of humanity, they will just come and blow it up" (Muslim faith leader, Nigeria). Whilst some initiatives targeted particular individuals, many others focused on changing relationships and attitudes within the whole community. This echoes the relational consciousness that many religions embrace — and that, incidentally, many liberal thinkers tend to downplay (Hay 2000):

We don't just tackle the youth who go and fight, we consider the women who cook for them and the men who buy them pure water, the politicians and the prominent men and women, and the market traders who sell guns.

(Faith-based development worker, Nigeria)

Relationships between religious leaders of different faiths were recognised as particularly important, as they have significant influence over their followers: "For us preventing violence means continuous dialogue. $99 \%$ of our work is conflict prevention. If leaders are talking, everyone will be calm" (Inter-faith worker, Zanzibar). The authenticity of relationship was also important, as, otherwise, initiatives lose legitimacy: "There are people in [the Muslim faith] I can trust. One imam is bent on telling the truth, he is educated in the Bible and the Quran. We call each other when things are bad" (Christian faith leader, Nigeria).

\subsection{The Reliance on ICTs in Conflict Prevention}

In the case studies, faith-based actors displayed varying levels of engagement with ICTs for conflict prevention. In some countries, such as Nigeria, organisations make substantial use of technology. In others, such as the Solomon Islands, they do not. The key factors mediating this appear to be the availability of communications infrastructure, local culture and donor priorities. None of 
the respondents idealised technology, and many emphasised that analogue communications are still relevant in their context. Flyers stir hostilities in Zanzibar markets; newspapers distort information in Nigeria. In the Solomon Islands, word of mouth is still a critical form of information exchange, given the low penetration and prohibitively high costs of modern telecommunications:

Not everyone has a radio. A newspaper costs 5 dollars-two packets of noodles. When people don't get information, they create their own information. And the coconut wireless is much faster than the mobile phones.

(RAMSI representative, Solomon Islands)

Generally, faith-based organisations were discerning in their use of technology, recognising when it helped and hindered. In some cases, respondents were wary because of instances in which technology has helped to incite violence by spreading rumours:

After [recent youth violence] we asked what caused the problem? The youth said rumours. This is the disadvantage of technology. The illiterate, semi-literate don't have the sense or time to say this sort of rumour is not true, or let me verify it. They just react.

(Muslim faith leader, Nigeria)

However, faith-based organisations are not invulnerable to technological misadventures either. One organisation ran a successful conflict early warning initiative based on monitoring teams comprised of local volunteers, who were able to refer issues to the organisation for early mediation. Based on this, an international donor offered to sponsor a technology-enhanced project whereby local people could report incidents by SMS, which could then be plotted on a GPS map in an incident room. Before long, the project became redundant-an expensive duplication of the existing initiative but requiring additional technical skill that few in the organisation had mastered.

\subsection{Short-Termism}

Where faith-based actors are reliant on donor funding, they are subject to the same timing issues encountered by other organisations. Often though, faith-based organisations have access to their own resources, which enables them to engage reflexively over a longer period of time. In the case studies, faith groups ran some activities that were intentionally short-term and operational, but much of their work was also structural, designed to break the cycle of violence over generations. Moreover, when respondents were asked about their perspective on timing, their call was not to speed up, but to slow down, and to invest in long-term initiatives that lay the foundations of peace:

To me, [conflict] prevention sounds like an immediate solution, but actually we need to do our homework. A whole generation has grown up with hatred in their hearts, in their families and communities. So we need to pay more attention there.

(Christian faith leader, Nigeria)

\section{Conclusions}

There has been a demonstrable "turn" to both religion and the local in recent years. This article investigates actors in both of these domains of conflict prevention, who in this case overlap, in order to question some of the conventional assumptions about prevention that emerge from its roots in liberal peace.

Having documented faith-based conflict prevention initiatives in three countries, this article has argued that in some cases they appear to make a meaningful impact in reducing violence. However, to what extent can the successes of local faith-based organisations be attributed to their localness, their faith-basis or both? Clearly, there are instances where localness is key, as this enables organisations to "read" situations and respond appropriately. However, there are also instances where an organisations' religious character can play a decisive role-for instance, in persuading former combatants to give up 
their weapons and be spiritually cleansed. Ultimately, the organisations in the study had both local capital and spiritual and religious capital and used them both.

In some ways, the faith-based approaches studied here conform with "liberal peace" wisdom, as they affirm the fundamental soundness of investing in conflict prevention through peacebuilding initiatives and the practical gains that can be made. This is unsurprising, as they exist within a wider liberal framework and use many of the same models and approaches. Faith-based approaches also provide some useful counterpoints, highlighting liberal peace's susceptibility to quick wins, formulas and technological solutionism. These are serious weaknesses within the liberal peace framework, identified through existing critiques, but none are insurmountable. Indeed, they could all be addressed through reform of the liberal peace agenda, or failing this, could be partially offset by adaptations in current programming. Faith-based approaches offer glimpses of such adaptations, many of which could be replicated by others. Firstly, they foreground values such as justice, compassion and human flourishing. For faith-based actors these values are religiously inspired, but they are also universal values that the wider peacebuilding sector can seek to engender. Secondly, faith-based approaches emphasise the importance of relationships, recognising their significance in explaining people's behaviour and motivation for change. This is habitual for many faith traditions, which stress relationality and the common good, but contrasts with the liberal peace view of the individual as self-governing. Thirdly, faith-based approaches allow participants to engage deeply, bringing in different dimensions of their experience, including spirituality and emotion.

Expanding our view of conflict prevention to include faith-based actors also addresses a methodological blind spot. Generalisations about conflict prevention are becoming more commonplace as the field develops, but they cannot hold true unless they capture the entirety of the endeavour, including initiatives that are faith-based, secular and hybrid. Faith-based initiatives require us to think about peacebuilding vernacular and how far it does and does not travel, and in so doing, it reminds us to scrutinise how accurately and strategically actors use the term "conflict prevention" in general.

The case study approach used in this article was adopted as a first step to exploring a largely unresearched topic. Based on its findings, several pathways for future research have emerged. A theological exploration of the underpinnings and expressions of conflict prevention norms in different faith traditions would add another dimension to existing insights. The current research has also focused on faith-based actors at the leadership level, but what about ordinary religious people? As one respondent would have it, "Many people have no sympathy for dialogue or prevention, they are not theologically convinced. We see the same faces in dialogues, they are interfaith practitioners. What about ordinary people, what theological basis do they have?" (Muslim faith leader, Zanzibar). Is this true, and if it is, does it matter? Finally, another dimension to explore lies in the differences between faith-based conflict prevention and countering violent extremism initiatives, which also involve religious groups in preventative actions. Would the two concepts provide similar insights into the liberal and the local, and if not, how would they differ?

Funding: This research was funded by the UK's Economic and Social Research Council through the Faith-based conflict prevention and early warning scoping project, grant number ES/L002116/1. The APC was funded by RCUK through a block grant to Coventry University. The Zanzibar Case Study was funded through Making All Voices Count, an initiative supported by the UK Department for International Development (DFID), the US Agency for International Development (USAID), the Swedish International Development Cooperation Agency (SIDA) and the Omidyar Network, and implemented by a consortium consisting of Hivos, IDS and Ushahidi.

Acknowledgments: Organisations that have contributed to the projects underpinning this research include the Anglican Alliance (UK), the Archbishop of Canterbury's Reconciliation Ministry (UK), the Action Support Centre (South Africa), Local Peace Committees in Gauteng Province (South Africa), People's Voice for Peace (Uganda) and the Zanzibar Interfaith Centre (Tanzania).

Conflicts of Interest: The author declares no conflict of interest. The funders had no role in the design of the study; in the collection, analyses, or interpretation of data; in the writing of the manuscript; or in the decision to publish the results. 


\section{References}

Abu-Nimer, Mohammed. 2003. Non-Violence and Peacebuilding in Islam: Theory and Practice. Gainesville: University Press of Florida.

Ager, Joey, Elena Fiddian-Qasmiyeh, and Alastair Ager. 2015. Local faith communities and the promotion of resilience in contexts of humanitarian crisis. Journal of Refugee Studies 28: 202-21. [CrossRef]

Aggestam, Karin. 2003. Conflict Prevention: Old Wine in New Bottles? International Peacekeeping 10: 12-23. [CrossRef]

Anderson, Mary B., and Marshall Wallace. 2012. Opting Out of War: Strategies to Prevent Conflict. Boulder: Lynne Rienner Publishers.

Appleby, R. Scott. 2000. The Ambivalence of the Sacred: Religion, Violence and Reconciliation. Lanham: Rowman and Littlefield Publishers.

Appleby, R. Scott. 2015. The new name for peace? Religion and development as partners in strategic peacebuilding. In The Oxford Handbook of Religion, Conflict and Peacemaking. Edited by Atalia Omer, Appleby R. Scott and David Little. New York: Oxford University Press.

Baker, Chris. 2009. Blurred encounters? Religious literacy, spiritual capital and language. In Faith in the Public Realm: Controversies, Policies and Practices. Edited by Adam Dinham, Robert Furbey and Vivien Lowndes. Bristol: Polity Press.

Bercovitch, Jacob, and S. Ayse Kadayifci-Orellana. 2009. Religion and Mediation: The Role of Faith-Based Actors in International Conflict Resolution. International Negotiation 14: 175-204. [CrossRef]

Boege, Volker, Anne Brown, Kevin Clements, and Anna Nolan. 2009. Building peace and political community in hybrid political orders. International Peacekeeping 16: 599-615. [CrossRef]

Bompani, Barbara. 2019. Religion and development: Tracing the trajectories of an evolving sub-discipline. Progress in Development Studies 19: 171-85. [CrossRef]

Bourdieu, Pierre. 1987. Legitimation and structured interests in Weber's sociology of religion. In Max Weber: Rationality and Modernity. Edited by Sam Whimster and Scott Lash. London: Allen and Unwin, pp. 119-36.

Bramsen, Isabel, and Paul Poder. 2018. Emotional Dynamics in Conflict and Conflict Transformation. Berlin: Berghof Foundaton.

Cavanaugh, William T. 1995. A fire strong enough to consume the house: The wars of religion and the rise of the state. Modern Theology 11: 397-420. [CrossRef]

Cavanaugh, William T. 2009. The Myth of Religious Violence: Secular Ideology and the Roots of Modern Conflict. New York: Oxford University Press.

Chalmers, Malcolm. 2006. Spending to save? The cost-effectiveness of conflict prevention. Defence and Peace Economics 18: 1-23. [CrossRef]

Chandler, David. 2010. The uncritical critique of 'liberal peace'. Review of International Studies 36: 137-55. [CrossRef]

Clarke, Gerald, Michael Jennings, and Timothy Shaw. 2008. Development, Civil Society and Faith-Based Organizations: Bridging the Sacred and the Secular. Basingstoke: Palgrave Macmillan.

Coote, Anna. 2012. The Wisdom of Prevention. London: New Economics Foundation.

De Juan, Alexander, and Jan Henryk Pierskalla. 2014. Civil war violence and political trust: Microlevel evidence from Nepal. Conflict Management and Peace Science 33: 67-88. [CrossRef]

Della-Giacoma, Jim. 2011. Preventative diplomacy in Southeast Asia: Redefining the ASEAN way. In Preventative Diplomacy: Regions in Focus. Edited by Francesco Mancini. New York: International Peace Institute, pp. $28-35$.

DfID. 2012. Faith Partnership Principles: Working Effectively with Faith Groups to Fight Global Poverty. London: DfID.

Duff, Jean, Mark Battcock, Azza Karam, and Adam Russell Taylor. 2016. High level collaboration between the public sector and religious and faith-based organizations: fad or trend? The Review of Faith and International Affairs 14: 95-100. [CrossRef]

Galtung, Johan, and Graheme MacQueen. 2008. Globalizing God: Religion, Spirituality and Peace. Germany: Transcend University Press.

Gopin, Marc. 2015. Negotiating secular and religious contributions to social change and peacebuilding. In The Oxford Handbook of Religion, Conflict and Peacemaking. Edited by Atalia Omer, Appleby R. Scott and David Little. New York: Oxford University Press.

Gough, Ian. 2013. The political economy of prevention. British Journal of Political Science 45: 307-27. [CrossRef] 
Guest, Matthew J. 2007. In search of spiritual capital: the spiritual as a cultural resource. In The Sociology of Spirituality. Edited by Keiran Flanagan and Peter C. Jupp. Aldershot: Ashgate, pp. 181-200.

Haider, Huma. 2016. Religious leaders and the prevention of election violence. GSDRC Applied Knowledge Services Helpdesk Research Report. Available online: https://gsdrc.org/wp-content/uploads/2016/07/HDQ1366.pdf (accessed on 3 April 2020).

Haufler, Virginia. 2004. International diplomacy and the privatization of conflict prevention. International Studies Perspectives 5: 158-63. [CrossRef]

Haufler, Virginia. 2010. The Kimberley Process Certification Scheme: An innovation in global governance and conflict prevention. Journal of Business Ethics 89: 403-16. [CrossRef]

Hauge, Wenche, Rachelle Doucet, and Alain Gilles. 2015. Building peace from below-The potential of local models of conflict prevention in Haiti. Conflict, Security and Development 15: 259-82. [CrossRef]

Hay, David. 2000. Spirituality versus individualism: Why we should nurture relational consciousness. International Journal of Children's Spirituality 5: 37-48. [CrossRef]

Haynes, Jeffrey. 2011. Religion, Politics and International Relations: Selected Essays. London: Routledge.

Hayward, Susan. 2015. Women, Religion, and Peacebuilding. In The Oxford Handbook of Religion, Conflict and Peacemaking. Edited by Atalia Omer, Appleby R. Scott and David Little. New York: Oxford University Press.

Hayward, Susan, and Katherine Marshall. 2015. Women, Religion, and Peacebuilding: Illuminating the Unseen. Washington: United States Institute of Peace Press.

Heelas, Paul L. F. 2002. The spiritual revolution: From 'religion' to 'spirituality'. In Religions in the Modern World. Edited by Linda Woodhead, Paul Fletcher, Kiroko Kawanami and David Smith. London: Routledge, pp. 357-77.

Hertog, Katrien. 2010. The Complex Reality of Religious Peacebuilding: Conceptual Contributions and Critical Analysis. Plymouth: Lexington Books.

Jacobsen, Katja Lindskov, and Troels Gauslå Engell. 2018. Conflict prevention as a pragmatic response to a twofold crisis: Liberal interventionism and Burundi. International Affairs 94: 363-80. [CrossRef]

Jeffrey, Renée, and Caitlin Mollica. 2017. The unfinished business of the Solomon Islands TRC: Closing the implementation gap. The Pacific Review 30: 532-48. [CrossRef]

Johnston, Douglas, and Cynthia Sampson. 1994. Religion, The Missing Dimension of Statecraft. Oxford: Oxford University Press.

Johnstone, Naomi, and Isak Svensson. 2013. Belligerents and believers: Exploring faith-based mediation in internal armed conflicts. Politics, Religion E Ideology 14: 557-79.

Keshodkar, Akbar. 2013. Tourism and Social Change in Post-Socialist Zanzibar: Struggles for Identity, Movement and Civilization. Plymouth: Lexington Books.

Kurtz, Gerrit, and Christoph O. Meyer. 2018. Is conflict prevention a science, art or craft? Moving beyond technocracy and wishful thinking. Global Affairs 5: 23-39. [CrossRef]

Langås, Arngeir. 2019. Peace in Zanzibar: Proceedings of the Joint Committee of Religious Leaders in Zanzibar, 2005-2013. New York: Peter Lang Publishing Inc.

Leach, Steven. 2016. Preventing Violence: Community-Based Approaches to Early Warning and Early Response. Zurich: ETH Zurich.

Leach, Steven, Richard Smith, Chas Morrison, and Laura Payne. 2015. Can ICT Innovation Adequately Support Conflict Prevention? Hivos Blog. January 14. Available online: https://knowledge.hivos.org/can-ictinnovation-adequately-support-conflict-prevention (accessed on 5 June 2019).

Lederach, John Paul. 2001. Five qualities of practice in support of reconciliation processes. In Forgiveness and Reconciliation: Religion, Public Policy \& Conflict Transformation. Edited by Raymond G. Helmick and Rodney L. Peterson. Philadelphia: Templeton Foundation Press, pp. 183-93.

Lederach, John Paul, and R. Scott Appleby. 2010. Strategic Peacebuilding: An Overview. In Strategies of Peace: Transforming Conflict in a Violent World. Edited by Daniel Philpott and Gerard F. Flowers. New York: Oxford University Press.

Lynch, Cecelia. 2015. Religious Communities and Possibilities for Justpeace. In The Oxford Handbook of Religion, Conflict and Peacemaking. Edited by Atalia Omer, Appleby R. Scott and David Little. New York: Oxford University Press.

Mac Ginty, Roger. 2018. The limits of technocracy and local encounters: The European Union and peacebuilding. Contemporary Security Policy 31: 166-79. [CrossRef] 
Mac Ginty, Roger, and Oliver P. Richmond. 2013. The local turn in peacebuilding: A critical agenda for peace. Third World Quarterly 34: 763-83. [CrossRef]

Martin-Shields, Charles. 2013. Inter-ethnic Cooperation Revisited: Why Mobile Phones Can Help Prevent Discrete Events of Violence, Using the Kenyan Case Study. Stability: International Journal of Security and Development 58: $1-13$.

Marx, Karl. 1844. Critique of Hegel's Philosophy of Right (Zur Kritik der Hegelschen Rechtsphilosophie), Deutsch-Französische Jahrbücher.

Matveeva, Anna. 2006. Early Warning and Early Response: Conceptual Empirical Dilemmas. The Hague: European Centre for Conflict Prevention.

Mullin, Corinna. 2010. Islamist challenges to the 'liberal peace' discourse: The case of Hamas and the Israel-Palestine 'peace process'. Millennium: Journal of International Studies 39: 525-46. [CrossRef]

Musa, Gerald. 2016. Negotiating mutuality through peace accords: Kaduna State as a case study. Peace and Change 41: 452-74. [CrossRef]

Neumaier, Eva. 2004. Missed opportunities: Buddhism and ethnic strife in Sri Lanka and Tibet. In Religion and Peacebuilding. Edited by Harold Coward and S. Smith Gordon. New York: SUNY Press, pp. 69-92.

Palihapitiya, Madhawa. 2018. Faith-based conflict early warning: Experiences from two conflict zones. The Journal of Interreligious Studies 24: 61-77.

Paris, Roland. 2010. Saving liberal peacebuilding. Review of International Studies 36: 337-65. [CrossRef]

Perchoc, Philippe. 2016. Religious Organisations and Conflict Resolution (PE 593.515). Brussels: European Parliamentary Research Service.

Philpott, Daniel. 2007. Explaining the political ambivalence of religion. American Political Science Review 101: 505-25. [CrossRef]

Putman, Katharine, Julia Lea, and Cynthia Eriksson. 2011. Cross-cultural comparison of religious coping methods reported by native Guatemalan and Kenyan faith-based relief providers. Journal of Psychology and Theology 39: 233-43. [CrossRef]

Putnam, Robert. 2000. Bowling Alone: The Collapse and Revival of American Community. New York: Simon and Schuster Paperbacks.

Richmond, Oliver. 2009. A post-liberal peace: Eirenism and the everday. Review of International Studies 35: 557-80. [CrossRef]

Richmond, Oliver P., and Roger Mac Ginty. 2015. Where now for the critique of the liberal peace? Cooperation and Conflict 50: 171-89. [CrossRef]

Sabaratnam, Meera. 2011. A liberal peace? A brief intellectual history of international conflict management, 1990-2010. In A Liberal Peace? The Problems and Practices of Peacebuilding. Edited by Susanna Campbell, David Chandler and Meera Sabaratnam. London: Zed Books.

Saferworld and Conciliation Resources. 2016. Effective Local Action: From Early Warning Peacebuilding. London: Saferworld and Conciliation Resources.

Sampson, Cynthia, and John Paul Lederach. 2000. From the Ground Up: Mennonite Contributions to Peaecebuilding. Oxford: Oxford University Press.

Shannahan, Chris, and Laura Payne. 2016. Faith-Based Interventions in Peace, Conflict and Violence: A Scoping Study, Joint Learning Initiative for Faith and Local Communities.

Toft, Monica Duffy, Daniel Philpott, and Timothy Samuel Shah. 2011. God's Century: Resurgent Religion and Global Politics. New York: W. W. Norton \& Co.

UNHCR. 2014. Partnership Note on Faith-Based Organizations, Local Faith Communities and Faith Leaders. Geneva: UNHCR.

United Nations and World Bank. 2018. Pathways for Peace: Inclusive Approaches to Preventing Violent Conflict. Washington, DC: World Bank.

Vanheusden, Els. 2010. Overview of the conflict prevention policy of the EU. MICRON Policy Working Paper 16. Brighton: University of Sussex.

Verkoren, Willemijn. 2006. Knowledge networking: Implications for peacebuilding activities. International Journal of Peace Studies 11: 27-62. 
Weber, Max. 1964. The Sociology of Religion. Boston: Beacon Press.

Wulf, Herbert, and Tobias Debiel. 2009. Conflict Early Warning and Response Mechanisms: Tools for Enhancing the Effectiveness of Regional Organisations? A Comparative Study of the AU, ECOWAS, GAD, ASEAN/ARF and PIF. London: LSE.

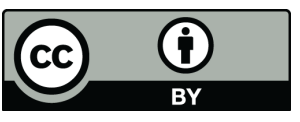

(C) 2020 by the author. Licensee MDPI, Basel, Switzerland. This article is an open access article distributed under the terms and conditions of the Creative Commons Attribution (CC BY) license (http://creativecommons.org/licenses/by/4.0/). 